Review article

UDC 628(282.243.7)(497.11)“2018”

Received: 03. July 2020

Received in revised form: 10. July 2020;

Accepted: 20. July 2000;

Available online: 12 . December 2020

\title{
THE ANALYSIS OF THE QUALITY OF SURFACE WATER OF DANUBE IN THE REPUBLIC OF SERBIA FOR 2018.
}

\author{
Uroš Durlević ${ }^{1}$
}

\begin{abstract}
Today, the quality of water in the world is changing significantly due to the increasing human impact on the environment. The paper presents an analysis of the surface water quality of the Danube river at five hydrological stations in Serbia for 2018. Using the relevant method - the water quality index, in this case, the Serbian water quality index (SWQI) ten physico-chemical and microbiological parameters (oxygen saturation, Five-Day Biochemical Oxygen Demand or BOD5, ammonium ion concentration, $\mathrm{pH}$ value, water) were analyzed Total Nitrogen or WTN, Total Suspended Solids or TSS, orthophosphate concentration, electrical conductivity, temperature and fecal coliform bacteria presence in water). The values obtained are classified in 5 classes depending on the water quality. The lowest (good) water quality was recorded on the Zemun - Smederevo river course, while in Bezdan, Novi Sad and Radujevac, the average annual water quality is very good.
\end{abstract}

Keywords: SWQI, Danube, Serbia, physico-chemical and microbiological parameters.

\section{Introduction}

Due to the increasing degradation of the environment by man, the quality of all media is called into question. Water is an essential element for all lifeforms, as well for the social and economical development of the mankind. It is anaturally regenerating medium, but its qualitative characteristics are vulnerableto polluters like waste, urban agglomeration, intensive agriculture and the lack of a good management in this field (Nistor et al., 2012).

1 Corresponding author: U. Durlević, University of Belgrade-Faculty of Geography, Belgrade; e-mail: durlevicuros@gmail.com 
To properly control the quality of surface water, it is necessary to have appropriate devices at the hydrological stations that will identify the concentrations of physical, chemical and microbiological parameters in the river course. The study of the quality and pollution of watercourses in the world is usually based on the application of various mathematical and statistical methods (Urošev et al., 2009; Milanović et al., 2011; Brankov et al., 2012; Pantelic et al., 2012; Takić et al., 2017).

This paper aims to determine the surface water quality of Danube on the territory of the Republic of Serbia during 2018. and to analyze the physicochemical and ecological parameters that participate in the Serbian Water Quality Index method. By the Law on Waters, to prevent deterioration of the quality of water and the environment, physicochemical parameters and emission limit values for pollutants are determined. In addition to the physicochemical, the ecological status of surface waters is also analyzed.

\section{Materials and Methods}

\section{Study area}

Publication of the Environmental Protection Agency, that contains the data from 5 hydrological stations was used to analyze the water quality of the Danube. These five stations are Bezdan, Novi Sad, Zemun, Smederevo and Radujevac. In this way, by selecting hydrological stations, it is possible to determine the water quality of the Danube at the entry and exit in the Republic of Serbia for 2018. The Danube is the second-longest river in Europe, with a length of $588 \mathrm{~km}$ through Serbia.

Table 1: Coordinates of hydrological stations

\begin{tabular}{|c|c|c|}
\hline Hydrological station & \multicolumn{2}{|c|}{ Coordinates } \\
\hline Bezdan & $45^{\circ} 51^{\prime} 50.832^{\prime \prime} \mathrm{N}$ & $18^{\circ} 51^{\prime} 14.949^{\prime \prime} \mathrm{E}$ \\
\hline Novi Sad & $45^{\circ} 13^{\prime} 28.219^{\prime}$ & $19^{\circ} 50^{\prime} 31.310^{\prime \prime}$ \\
\hline Zemun & $44^{\circ} 50^{\prime} 55.788^{\prime \prime}$ & $20^{\circ} 25^{\prime} 01.984^{\prime}$ \\
\hline Smederevo & $44^{\circ} 41^{\prime} 37^{\prime}$ & $20^{\circ} 57^{\prime} 52.805^{\prime}$ \\
\hline Radujevac & $44^{\circ} 15^{\prime} 45.450 "$ & $22^{\circ} 41^{\prime} 09.577^{\prime}$ \\
\hline
\end{tabular}

The water quality of the Danube was analyzed at a total length of $576.2 \mathrm{~km}$, or $6.2 \mathrm{~km}$ after the entry of the Danube into Serbia, to $5.6 \mathrm{~km}$ before leaving the country. The average annual flow during 2018. was $2036 \mathrm{~m}^{3} / \mathrm{s}$ in Bezdan and $2626 \mathrm{~m}^{3} / \mathrm{s}$ in Novi Sad. After the confluence of the Sava, Tisza and Tamis into the Danube, the river flow in Smederevo is much higher and amounts to 4839 $\mathrm{m}^{3} / \mathrm{s}$. 


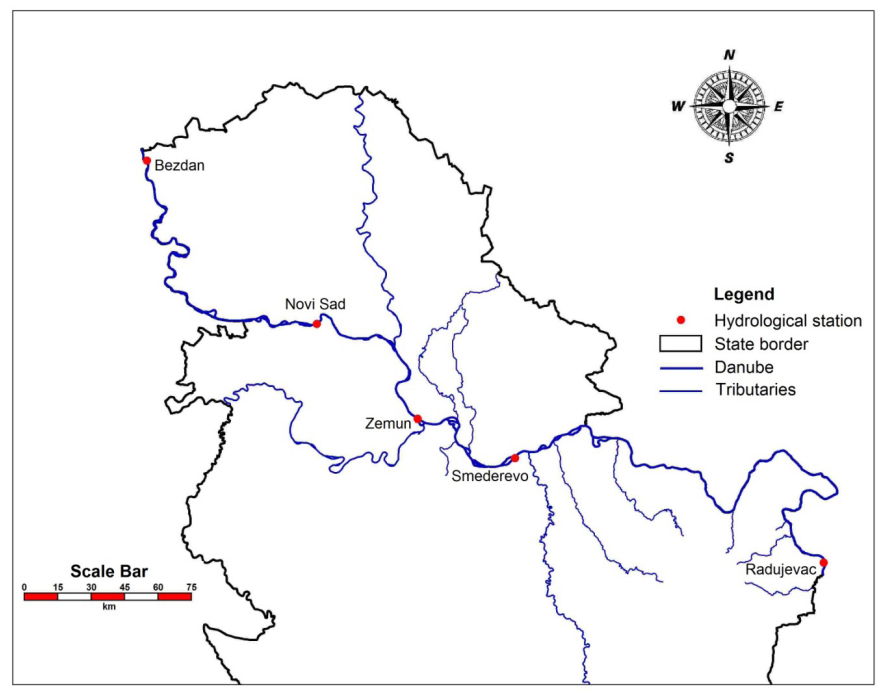

Figure 1. Danube course and its largest tributaries in Serbia

\section{Metodology}

In recent years, the analyses of watercourse quality based on mathematical indexes have become increasingly common. Authors from all over the world use the Water Quality Index as a reliable indicator of watercourse pollution (Bordalo et al., 2006; Lumb et al., 2006; Bharti \& Katyal, 2011; Jakovljević, 2012; Singh et al., 2013; Tyagi et al., 2013; Ismail \& Robescu, 2017).

Serbian Water Quality Index is environmental indicator, developed by Serbian Environmental Protection Agency (SEPA), based on method Water Quality Index (Development of a Water Quality Index, Scottish Development Department, Engineering Division, 1976; Jakovljević, 2012). This is an efficient method to indicate the current water quality and its trend in the observed area. The Water Quality Index was adopted by the European Union as a water quality assessment tool. In order to reduce the riskfor aquatic ecosystems, especially water quality, the experience of developed countries should be used (Zhukinskii, 2003). In Serbia, this method was used inan analysis of the water quality of the Danube River and the Danube-Tisza-Danube channel system (Veljković \& Jovičić, 2007; Milanović et al., 2011). The index is a useful tool for communicating water quality information to the large public and to legislative decision makers; it is not a complex predictive model for technical and scientific application (Hallock, 2002; Yogendra, 2008). 
The Water Quality Index (WQI) method combines standardized values (qi) of ten parameters, which describe the properties of surface waters to calculate a unique index value. This study reveals how these wide variations in different parameters can be reduced to a single number when reported with the help of WQI, thereby making it quite convenient to comment on the overall quality of the water sample from its pollution point of view (Kankal et al., 2012, S. P. Gorde et al., 2013).

The ten parameters have different relative significance for the overall water quality. Therefore, each parameter was assigned a weighting factor $\left(\mathrm{w}_{\mathrm{i}}\right)$ and a number of points in accordance with the threat they pose to water quality. By summing up the products of the $\mathrm{q}_{\mathrm{i}}$ and $\mathrm{w}_{\mathrm{i}}$ values we arrive at an index value of 100 as an ideal sum of the values of particular parameters (Milijašević Joksimović et al., 2018; Breabăn et al., 2012).

The SerbianWater Quality Index (SWQI) examines the following parameters:

- Oxygen saturation (\%)

- Five-Day Biochemical Oxygen Demand - $\mathrm{BOD}_{5}(\mathrm{mg} / \mathrm{l})$

- Ammonium ion concentracion (mg/l)

- $\mathrm{pH}$ value

- Water Total Nitrogen - WTN (mg/l)

- Orthophosphate concentration(mg/l)

- Total Suspended Solids - TSS (mg/l)

- Water temperature $\left({ }^{\circ} \mathrm{C}\right)$

- Electrical conductivity $(\mu \mathrm{S} / \mathrm{cm})$

- Fecal coliform bacteria (in $100 \mathrm{ml}$ )

In case we miss the value of some parameter, the value ofthe arithmetically calculated WQI is corrected by multiplying the index with the $1 / x$ value, where $x$ represents the sum of the arithmetically calculated weighting factors of available parameters (Veljković et al., 2008).

The arithmetic formulation for the WQI is of the form:

$$
\mathrm{WQI}=\sum_{i=1}^{n} q i \cdot w i
$$

where WQI is the water quality index, and is a number on the continuous scale from 0 to $100, n$ - number of parameters, qi - the water quality of the $i$-thparameter, wi - the weight attributed to the $i$-th parameter (Veljković et al., 2000).

At the end of the water quality calculation, a corresponding numerical value is obtained. The Serbian Water Quality Index method is used to classify the numeric indicator. 
Table 2. Classification criteria standards according to the Serbian Water Quality Index

\begin{tabular}{|c|c|c|}
\hline Serbian WQI & Descriptor category & Color \\
\hline $100-90$ & Excellent & \\
\hline $84-89$ & Very good & \\
\hline $72-83$ & Good & \\
\hline $39-71$ & Bad & \\
\hline $0-38$ & Very bad & \\
\hline
\end{tabular}

Source: www.sepa.gov.rs

The Water Quality Index classifies numerical values into one of five groups, depending on the quality of surface water. Water quality can be: excellent, very good, good, bad and very bad.

\section{Results and discussion}

During the 12 months of 2018., 5 hydrological stations calculated SWQI and the average annual value of each parameter of surface water quality.

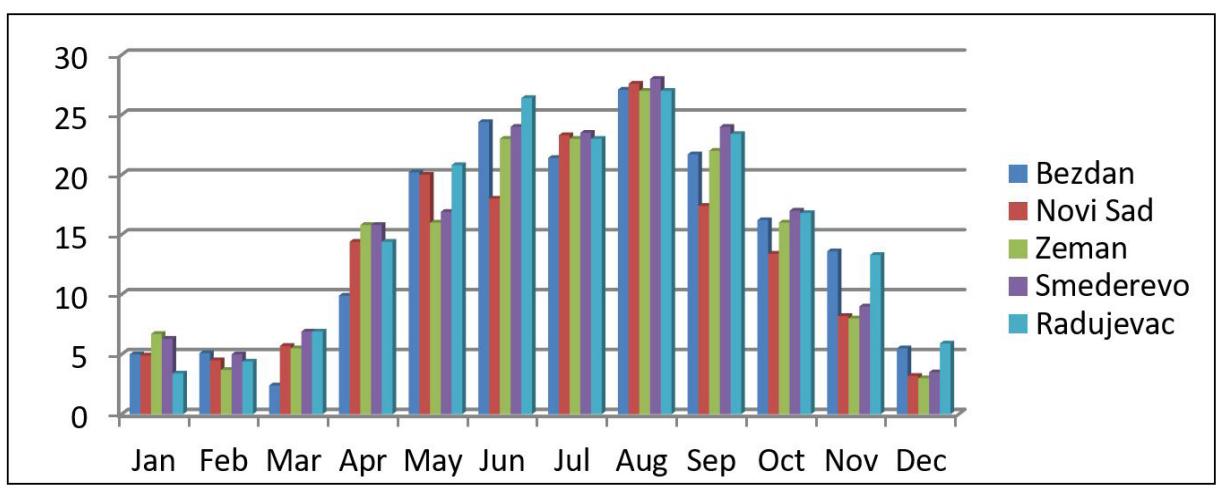

Figure 2. Water temperature $\left({ }^{\circ} \mathrm{C}\right)$ during 2018.

The water temperature is the lowest in the winter months and ranges from $3-6^{\circ} \mathrm{C}$ in all parts of the Danube, while the highest temperature was recorded in August (above $26^{\circ} \mathrm{C}$ ). When the water temperature is $>17^{\circ} \mathrm{C}$, it causes a decrease in its quality. Water temperature is essential for the process of self-purification of water and has significant effects on water life. Toxicity of the metals, the speed of chemical processes, the solubility of the gases, and the deposition of the suspended particles depend on temperature. 


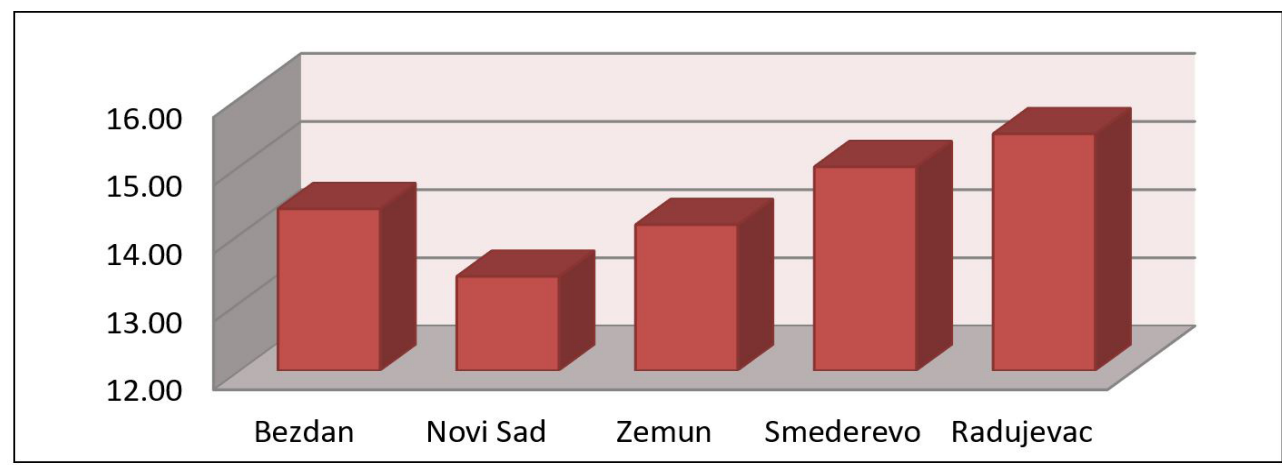

Figure 3. Average annual water temperature $\left({ }^{\circ} \mathrm{C}\right)$

The highest average water temperature is in Radujevac, while the lowest is in Novi Sad. Increased water temperature may indicate a higher presence of pollutants generated by various anthropogenic activities.

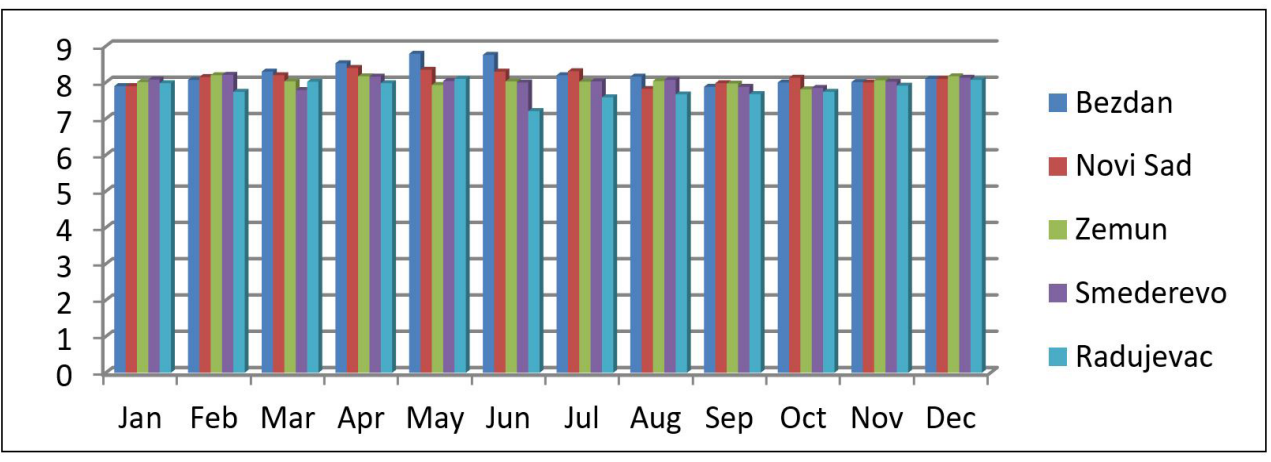

Figure 4. Water pH value during 2018.

The $\mathrm{pH}$ scale ranges from 0 (very acidic) to 14 (very basic). The $\mathrm{pH}$ value of water in all tested hydrological stations ranges from 7-9, which means that for most of the year, water has a neutral or slightly basic value. Chemically pure water at $25^{\circ} \mathrm{C}$ has a $\mathrm{pH}$ value of 7 (neutral). Natural waters generally have a $\mathrm{pH}$ of 4.5 to 8.3 , which depends on the balance between the carbon dioxide and the bicarbonate ion. Acidic water contains hydrolysis of salts, and base value water contains waste base substances. Acid and base water are harmful because they corrode the pipeline or cause sludge formation (Драгићевић и други., 2008). 


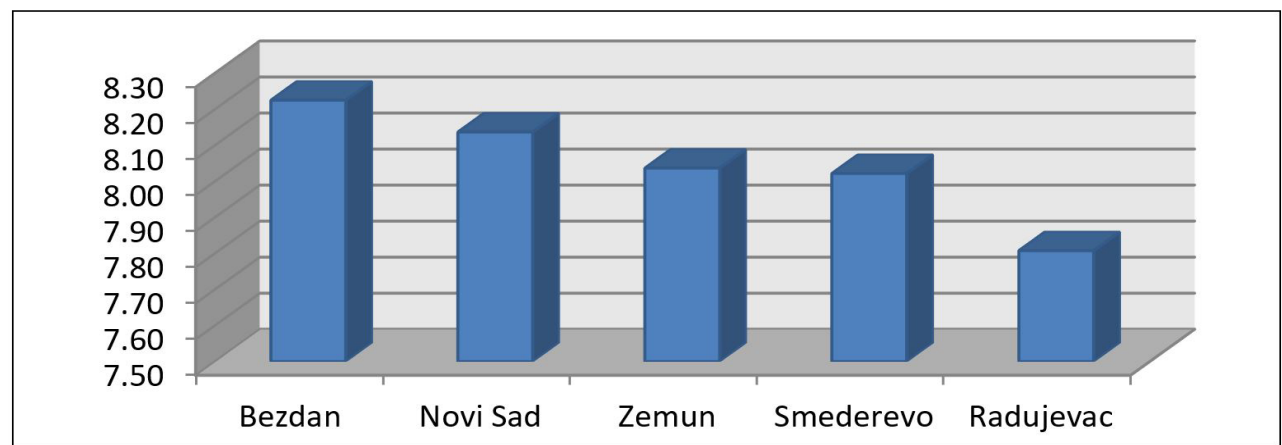

Figure 5. Average annual pH value of water during 2018.

The highest average $\mathrm{pH}$ value was recorded at the Danube entry into Serbia at the Bezdan hydrological station, while the lowest $\mathrm{pH}$ value at the Danube exit at Radujevac. When it comes to this parameter, it is noticeable that the slightly basic value does not significantly impair the water quality.

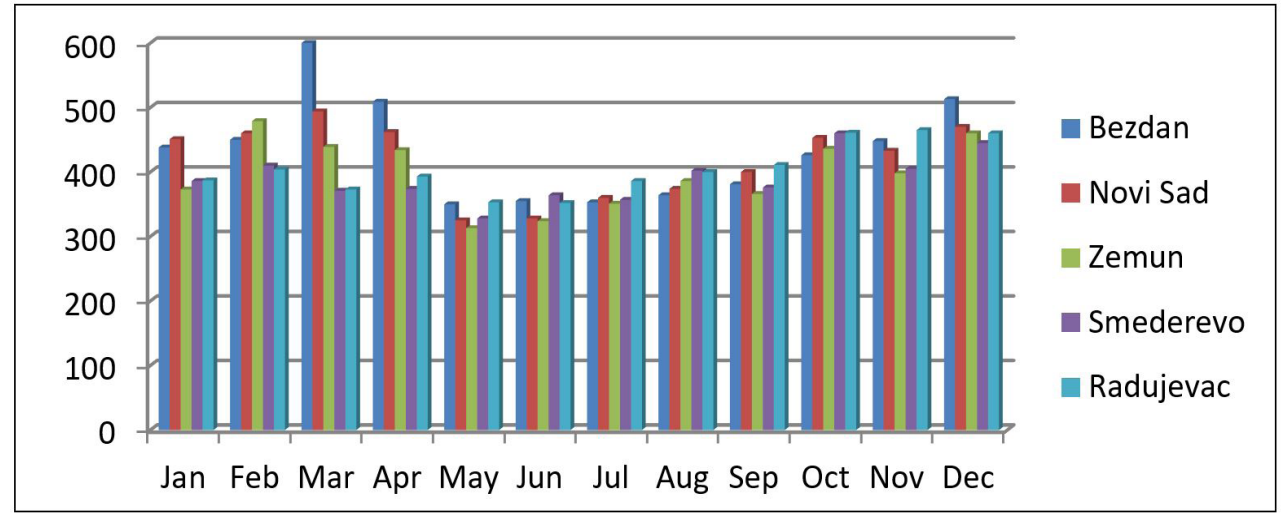

Figure 6. Electrical Conductivity of the Danube water $(\mu \mathrm{S} / \mathrm{cm})$

The conductivity $k$, is the electrical property of water. Water and aqueous solutions, depending on the ion concentration, can conduct electricity. The conductivity depends on the ions present in the water, their concentration, mobility and electric charge. It also depends on the temperature at which the conductivity is determined. At all tested hydrological stations, the conductivity valuesof water are in the range 313-600 $\mu \mathrm{S} / \mathrm{cm}$. Excellent water quality requires an electrical conductivity of less than $200 \mu \mathrm{S} / \mathrm{cm}$. 


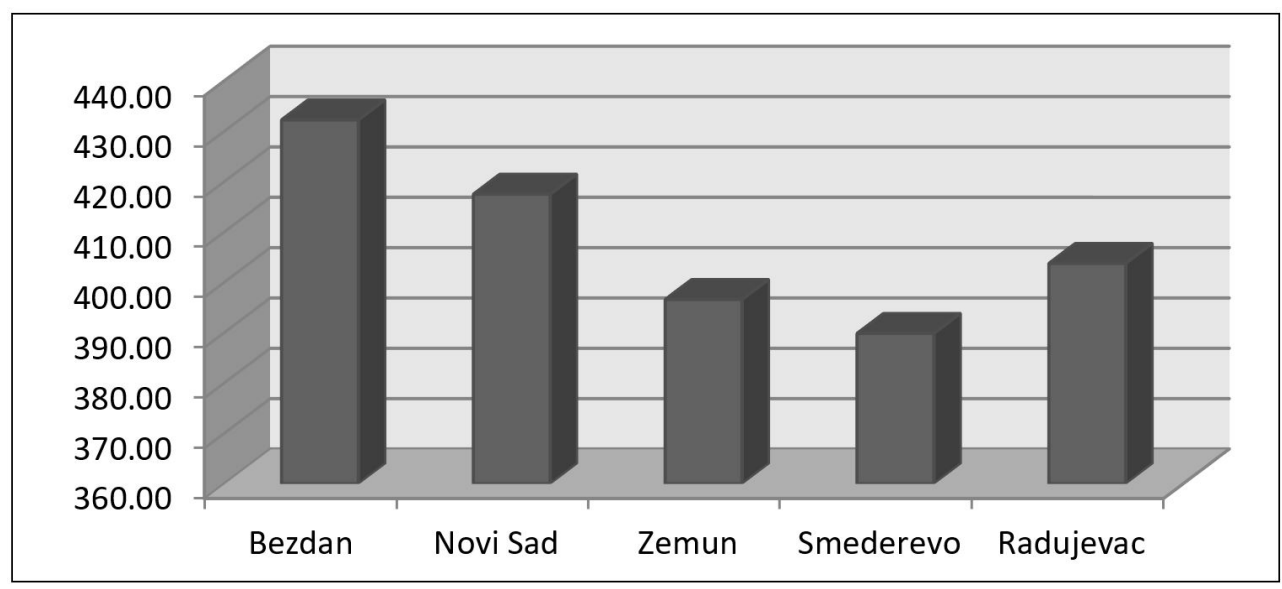

Figure 7. Average annual electrical conductivity $(\mu \mathrm{S} / \mathrm{cm})$ for 2018.

The lowest average electrical conductivity of water was recorded at the hydrological station in Smederevo $(389.83 \mu \mathrm{S} / \mathrm{cm})$, while the highest average value was recorded in Bezdan $(432.25 \mu \mathrm{S} / \mathrm{cm})$. Such values of electrical conductivity of water do not significantly affect the quality of surface water.

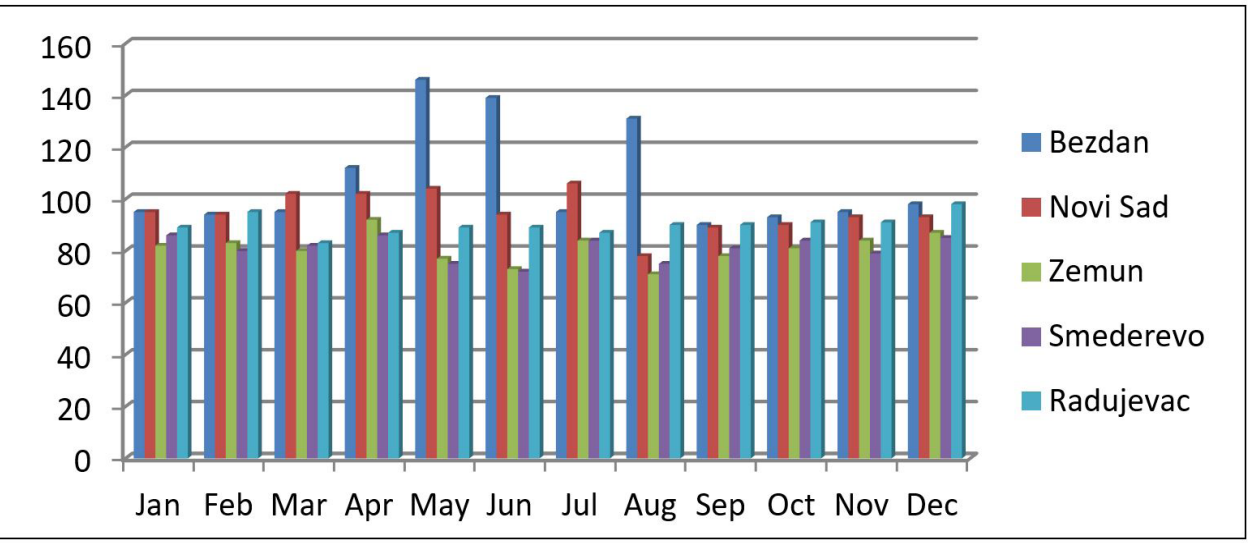

Figure 8. Oxygen saturation in water (\%)

The degree of oxygen saturation depends directly on the temperature and intensity of the photosynthesis process in the water. In conditions of low dissolved oxygen concentration, aquatic ecosystems become imbalanced, which can lead to fish death and an unpleasant smell (Mladenović-Ranisavljević, 2012). By far the highest oxygen saturation was recorded at a hydrological station in the Bezdan. Oxygen water saturation, together with $\mathrm{BOD}_{5}$, has the highest score in calculating SWQI. 


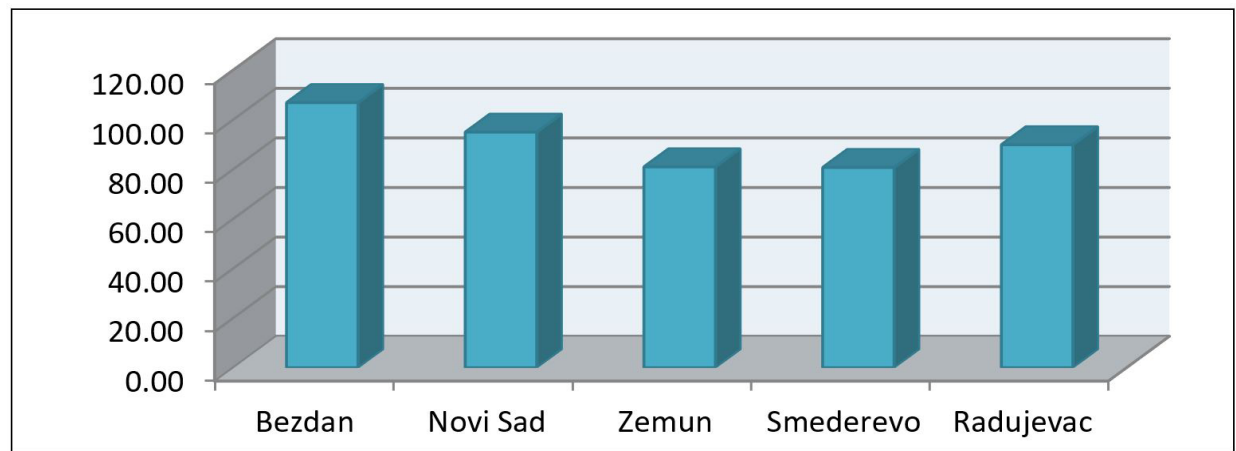

Figure 9. Average annual oxygen saturation (\%)

The average water saturation of the Danube was in Bezdan - 106.92\%, while the lowest recorded saturation was in Zemun (81\%) and Smederevo station $(80.75 \%)$. At all hydrological stations except Bezdan, oxygen saturation is not sufficient for excellent quality. For excellent water quality, oxygen saturation should be $93-110 \%$. The five-day biochemical oxygen demand $\left(\mathrm{BOD}_{5}\right)$ is the amount of oxygen dissolved in the water needed for the oxidation and decomposition of organic material. If the biochemical oxygen demand is high, it may indicate water pollution caused by the excessive decay of the material. With increasing temperature, the rate of oxygen consumption increases (MladenovićRanisavljević, 2012).

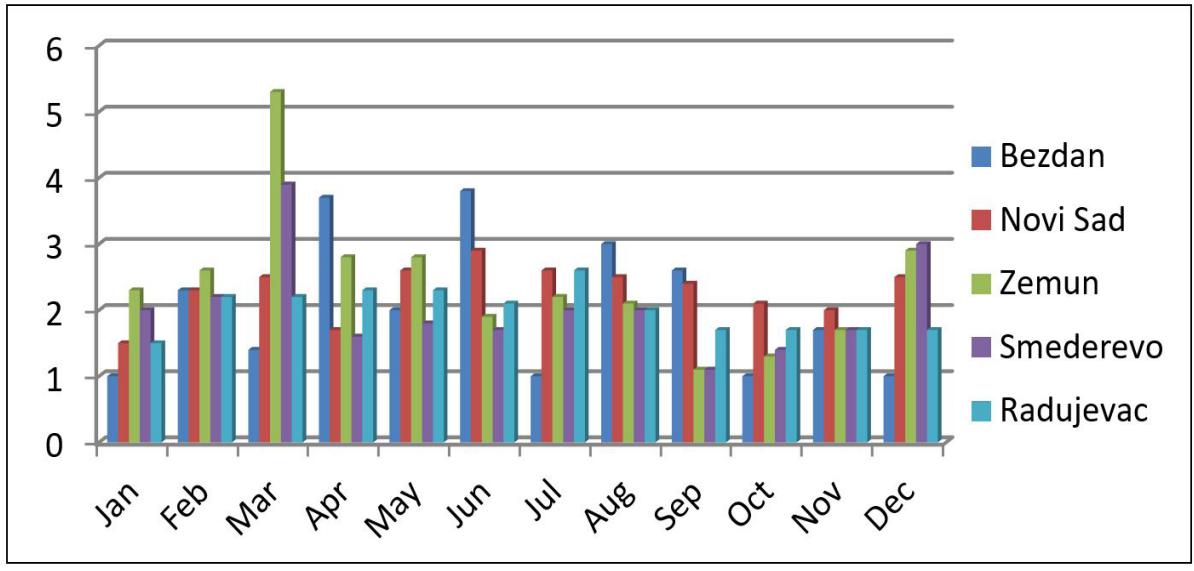

Figure 10. BOD5 value during 2018. (mg/l)

The value of biochemical oxygen consumption in all hydrological stations varies in the range of 1-4 mg/l. The most significant deviation was observed in Zemun in March when $\mathrm{BOD}_{5}$ was as high as $5.3 \mathrm{mg} / 1$. 


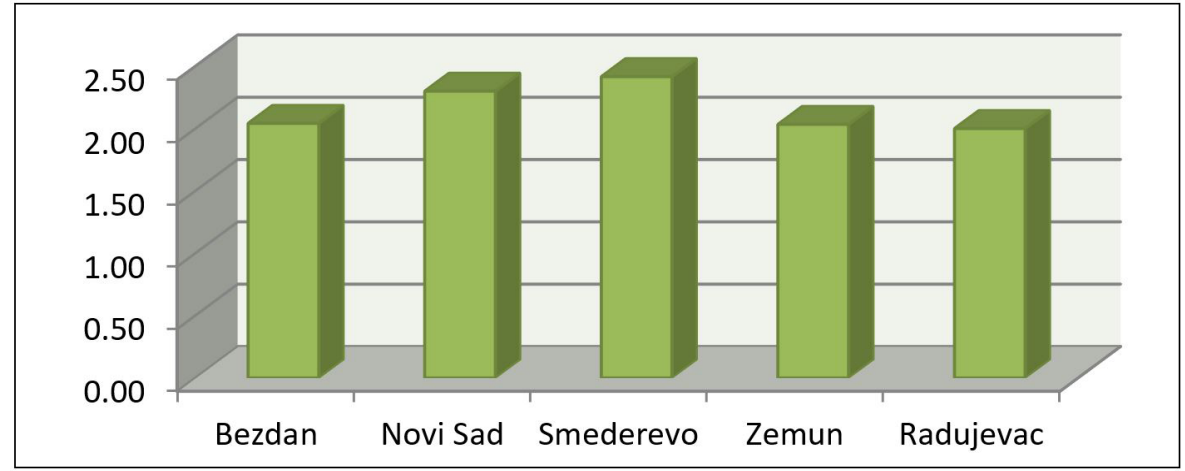

Figure 11. Average annual BOD5 $(\mathrm{mg} / \mathrm{l})$

The lowest average $\mathrm{BOD}_{5}$ value was measured in Radujevac $(2 \mathrm{mg} / \mathrm{l})$, while the highest value was recorded in Smederevo $(2.42 \mathrm{mg} / \mathrm{l})$. All measured values significantly affect the quality of surface water. It is necessary to carry out the testing, control and implementation of appropriate actions for the suppression of the excessive amount of organic matter in this part of the Danube. Excellent water quality requires a $\mathrm{BOD}_{5}$ concentration of less than $1 \mathrm{mg} / \mathrm{l}$.

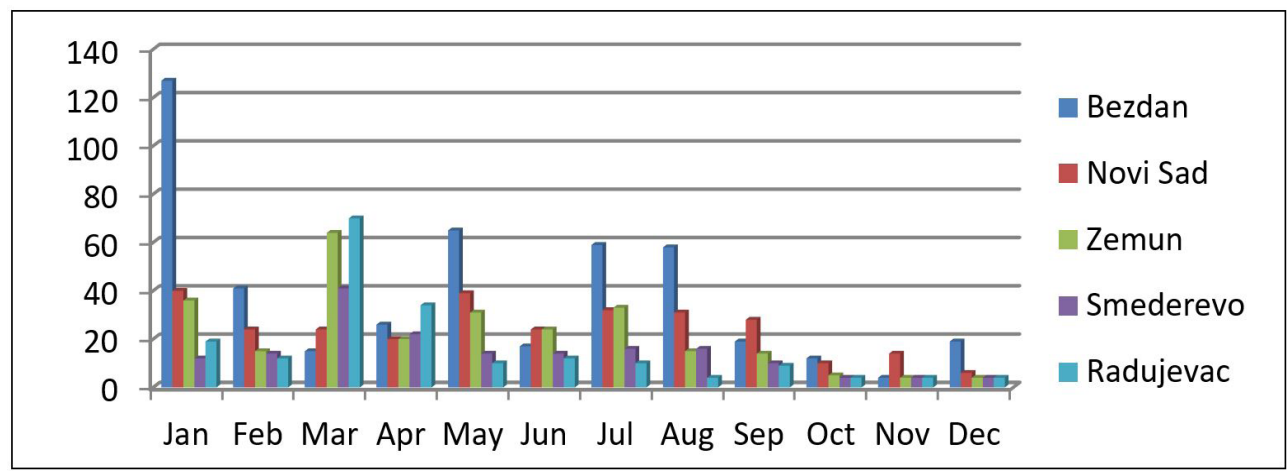

Figure 12. Total Suspended Solids $(m g / l)$

The concentration of suspended solids varies from one hydrological station to another. In the territory of Serbia and the stations from the study, the suspended solids have a significant impact on the reduction of water quality. The value of suspended particles was high, especially in the Bezdan, where a maximum of $127 \mathrm{mg} / 1$ was recorded during January. 


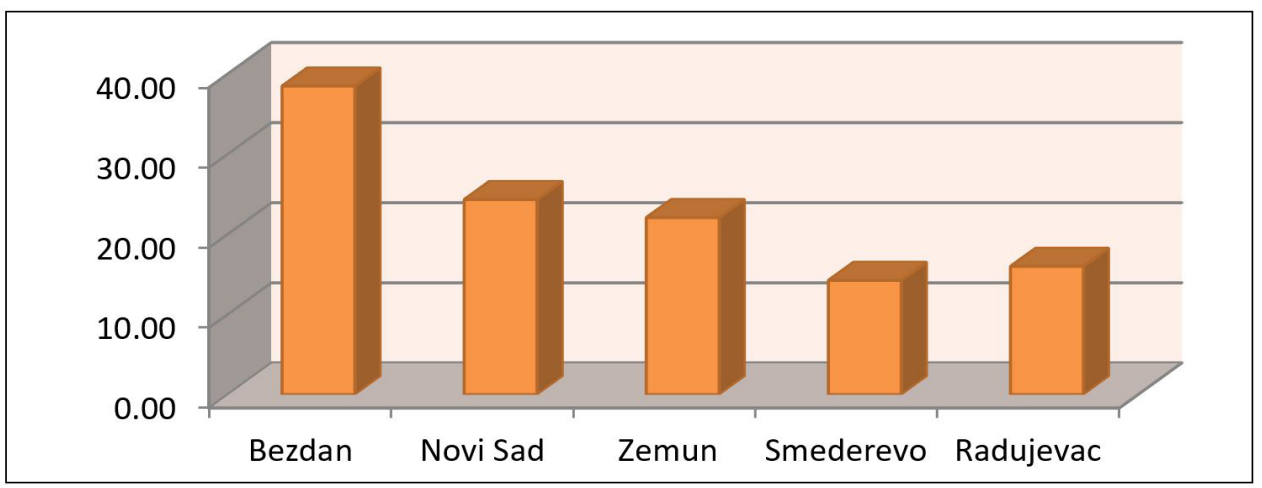

Figure 13. Average annual suspended solids concentration (mg/l)

On average, in 2018, the highest amount of suspended solids was recorded in Bezdan $(38.5 \mathrm{mg} / \mathrm{l})$ and the lowest in Smederevo $(14.25 \mathrm{mg} / \mathrm{l})$. The concentration of suspended solids depends on several factors: hydrological, geological, climatic, geomorphological, etc. Loose geological substrates in the territory of Vojvodina, can increase the concentration of suspended solids, while tributaries of the Danube flowing through the same or similar substrate can only further increase the concentration of suspended material. Also, great importance has the amount of precipitation in the study area. The water of excellent quality should have a concentration of suspended solids of $<10 \mathrm{mg} / 1$.

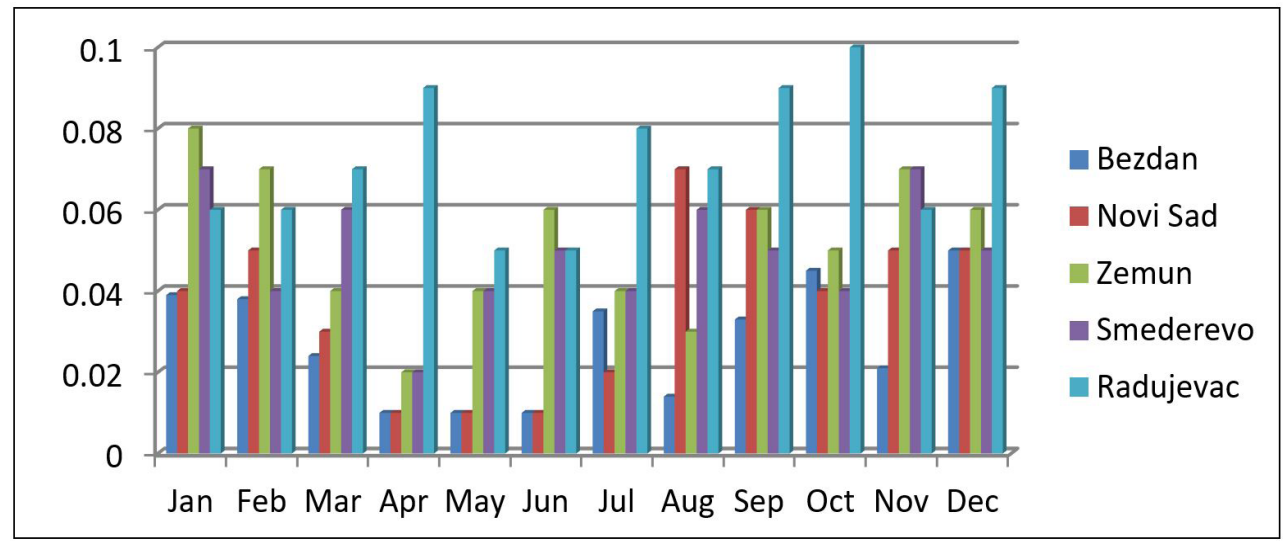

Figure 14. Orthophosphate concentration $(m g / l)$

Significant variations during the year occur in the content of orthophosphates in water. Phosphorus is a limiting factor in controlling algal overgrowth and accelerated eutrophication (Mladenović-Ranisavljević, 2012). For excellent 
water quality, the orthophosphate content should be less than $0.05 \mathrm{mg} / \mathrm{l}$. The lowest values occur in the summer months at all hydrological stations except in Radujevac, where maximums $(0.09-1 \mathrm{mg} / \mathrm{l})$ have been recorded.

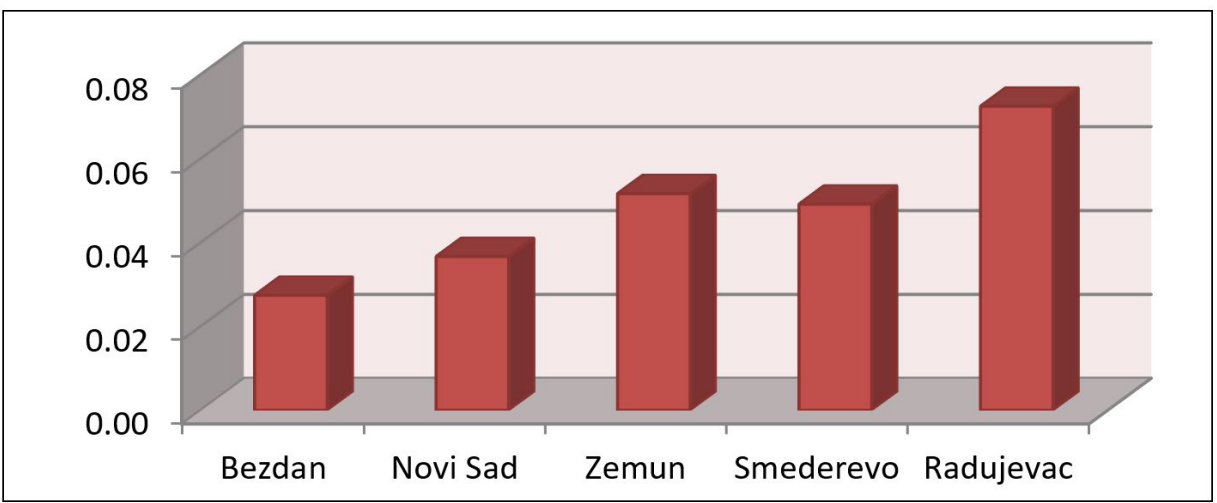

Figure 15. Average annual orthophosphate concentration (mg/l)

Excessive concentration of orthophosphates can indicate pollution caused by inadequate wastewater management, which is discharged from households and industrial plants. The lowest level of orthophosphates is at the entry of the Danube into Serbia $(0.03 \mathrm{mg} / \mathrm{l})$, and the highest at the exit of the Danube from the country $(0.07 \mathrm{mg} / \mathrm{l})$.

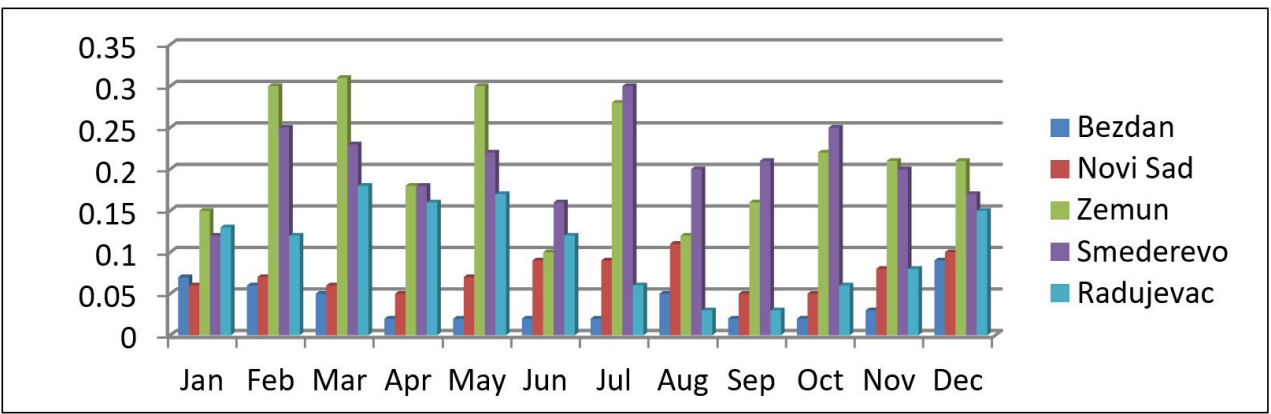

Figure 16. Ammonium ion concentration ( $m g / l)$

By far the highest ammonium ion content was recorded at hydrological stations in Zemun and Smederevo. Maximum values range from 0.25-0.31 mg/l, while the ideal value is below $0.1 \mathrm{mg} / \mathrm{l}$. In the water, ammonium exists in the form of ions $\left(\mathrm{NH}_{4}^{+}\right)$or the form of ammonia gas $\left(\mathrm{NH}_{3}\right)$. Increase of ammonia in water is related to an increase in temperature and a decrease in the concentration of oxygen in water (Mladenović-Ranisavljević, 2012). 


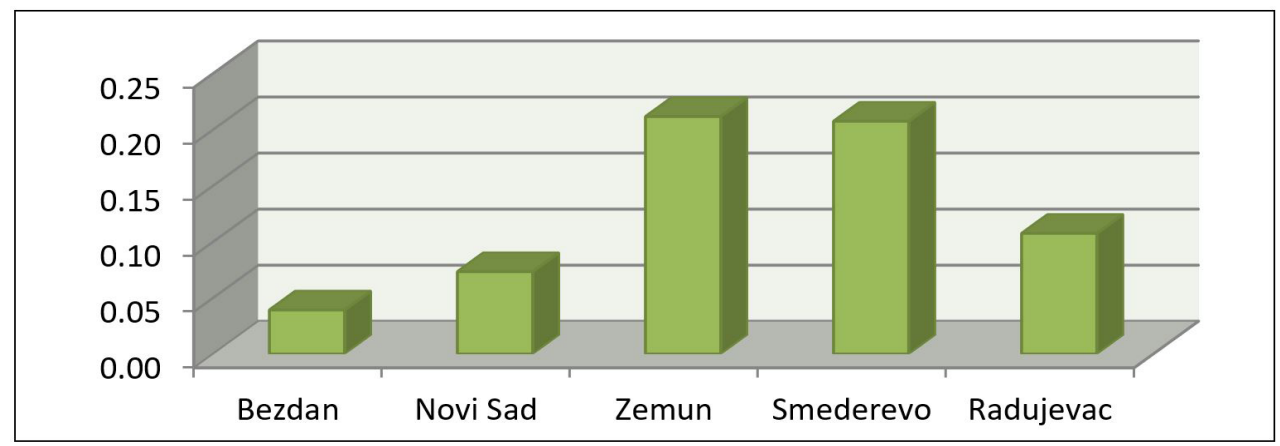

Figure 17. Average annual ammonium ion concentration $(\mathrm{mg} / \mathrm{l})$

Ammonium ion content does reduce the quality of surface water in the Bezdan and Novi Sad. The lowest $\mathrm{NH}_{4}^{+}$values were recorded in Bezdan $(0.04$ $\mathrm{mg} / \mathrm{l})$, while the highest values were identified in Zemun and Smederevo $(0.21$ $\mathrm{mg} / \mathrm{l}$ ) and represent a risk to water quality.

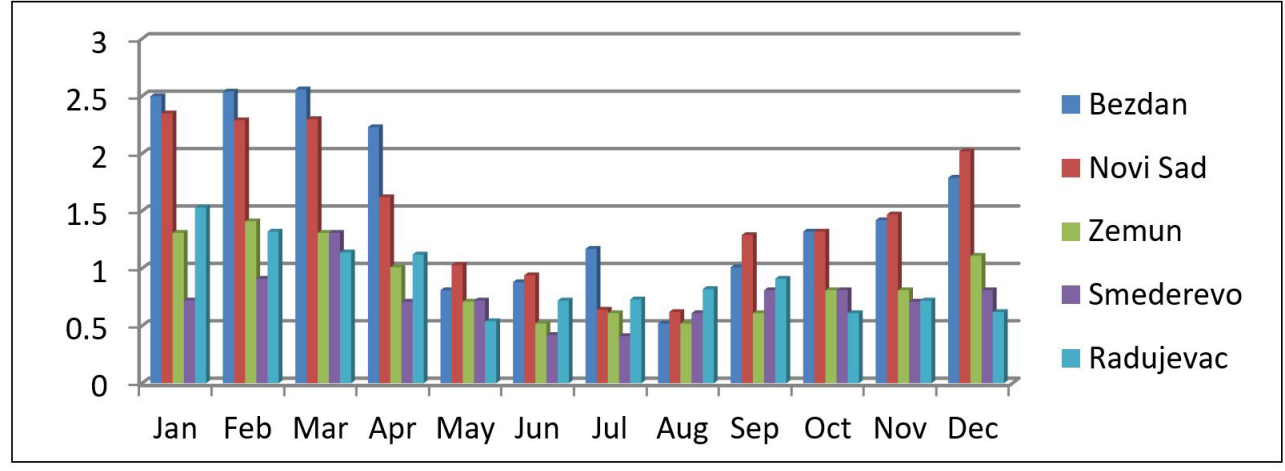

Figure 18. Total nitrogen oxides $(m g / l)$

Total nitrogen oxides represent the sum of nitrates and nitrites in the water. Nitrites, together with nitrates at higher concentrations, can cause significant health problems (Mladenović-Ranisavljević, 2012). The highest levels of nitric oxide are recorded in Bezdan and Novi Sad, where values in some months exceed 2 and $2.5 \mathrm{mg} / 1$. For the excellent quality of water, the amount of nitric oxide must be less than $0.5 \mathrm{mg} / 1$. 


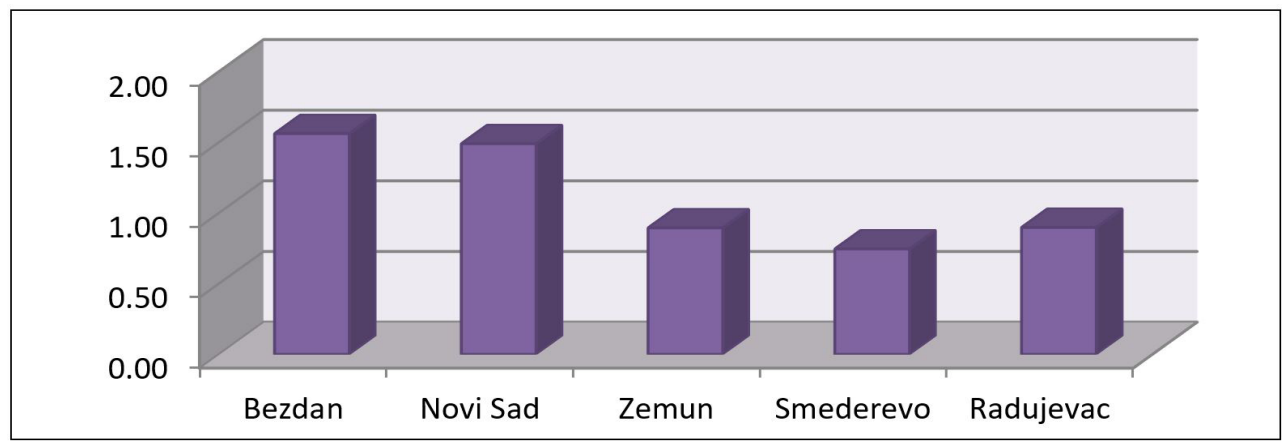

Figure 19. Average annual concentration of nitrogen oxide $(m g / l)$

The highest concentration of nitrite and nitrate occurs in Bezdan (1.56 $\mathrm{mg} / \mathrm{l})$, while the lowest is recorded in Smederevo $(0.75 \mathrm{mg} / \mathrm{l})$. At all stations, total nitrogen oxides affect the decrease in water quality. The last but also a very significant parameter in the overall calculation of the water quality index is the presence of fecal coliform bacteria.

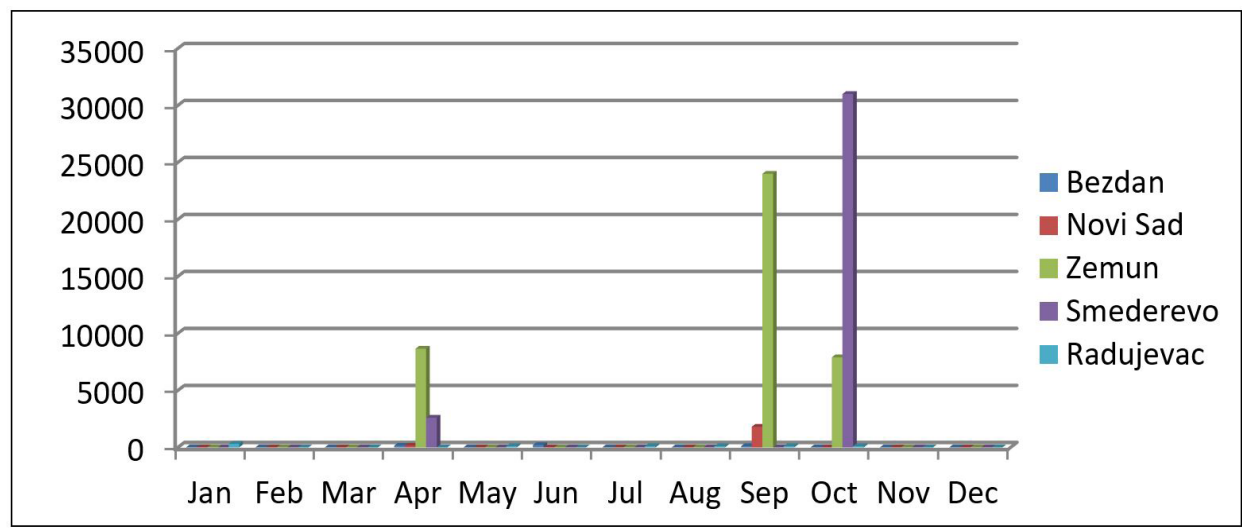

Figure 20. Fecal coliform bacteria in water (in $100 \mathrm{ml}$ )

For most of the year, coliforms do not appear at all in most hydrological stations. During April, September and October, a vast number of coliform bacteria appeared in Zemun. For excellent water quality, there has to be a complete absence of bacteria or content of $<300$ coliforms in water. For most of the year, the presence of bacteria was not recorded at the hydrological stations, but a large number of coliform bacteria appeared in some months. By far, the most significant amount of coliform bacteria was recorded in Zemun (40.550), in Smederevo 33.600, and Radujevac 810. In Bezdan, coliform bacteria do not affect water quality while in Novi Sad, bacteria decrease water quality during September. 


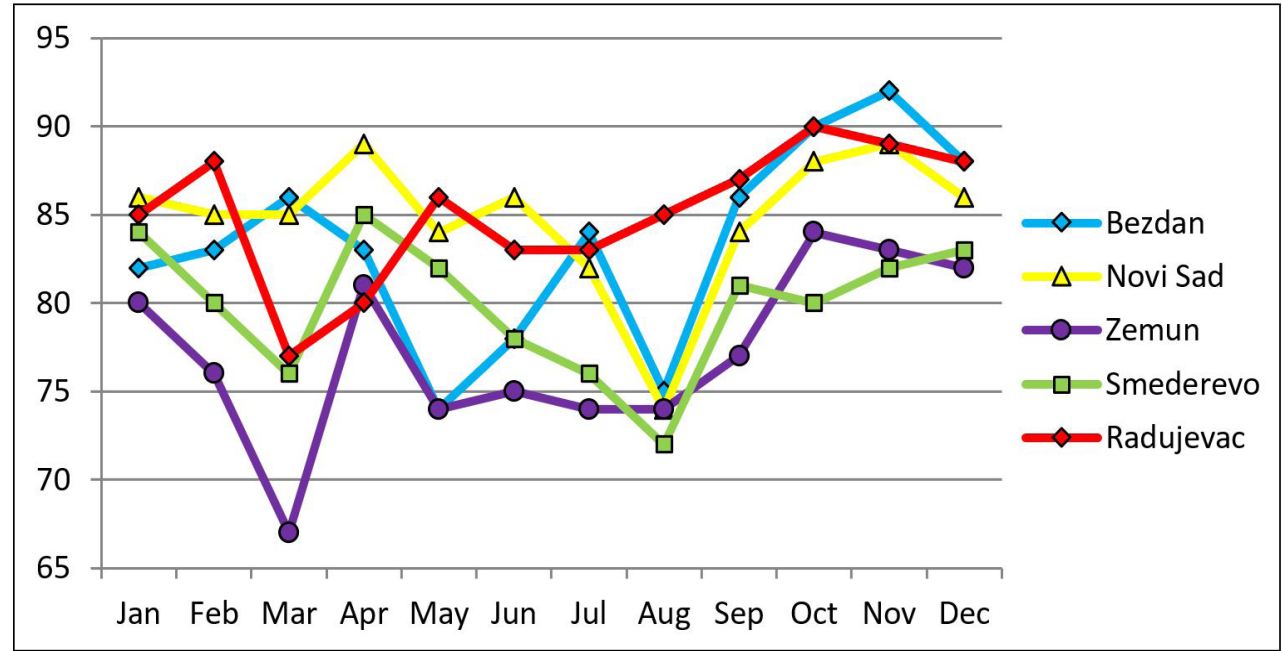

Figure 21. Water quality index by months for 2018.

Surface water quality was determined based on the analysis and calculation of the values of all parameters during the 12 months in 2018.

Table 3. Surface water quality in 2018.

\begin{tabular}{|c|c|c|c|c|c|c|c|c|c|c|c|c|c|c|}
\hline & I & II & III & IV & $\mathbf{V}$ & VI & VII & VIII & IX & $\mathbf{X}$ & $\mathbf{X I}$ & XII & A & AWQ \\
\hline B & 82 & 83 & 86 & 83 & 74 & 78 & 84 & 75 & 86 & 90 & 92 & 88 & 87 & $\begin{array}{c}\text { Very } \\
\text { good }\end{array}$ \\
\hline NS & 86 & 85 & 85 & 89 & 84 & 86 & 82 & 74 & 84 & 88 & 89 & 86 & 88 & $\begin{array}{c}\text { Very } \\
\text { good }\end{array}$ \\
\hline $\mathbf{Z}$ & 80 & 76 & 67 & 81 & 74 & 75 & 74 & 74 & 77 & 84 & 83 & 82 & 80 & Good \\
\hline $\mathbf{S}$ & 84 & 80 & 76 & 85 & 82 & 78 & 76 & 72 & 81 & 80 & 82 & 83 & 81 & Good \\
\hline $\mathbf{R}$ & 85 & 88 & 77 & 80 & 86 & 83 & 83 & 85 & 87 & 90 & 89 & 88 & 87 & $\begin{array}{c}\text { Very } \\
\text { good }\end{array}$ \\
\hline
\end{tabular}

Note: B-Bezdan, NS-Novi Sad, Z-Zemun, S-Smederevo, R-Radujevac; A-Average, AWQ-

Average water quality

On the yearly bases hydrological stations in Bezdan, Novi Sad and Radujevac record very good water quality of the Danube. During October and November, stations in Bezdan and Radujevac registers excellent water quality while in Zemun and Smederevo, the water quality is good on an annual basis. The lowest water quality was recorded in Zemun. In March, this station records bad water quality due to the increased $\mathrm{BOD}_{5}$ concentration. 


\section{Conclusion}

The water quality of the Danube when entering and leaving Serbia, is very good. During the autumn and winter of 2018, water quality in this area is slightly higher than in other periods of the year. What disrupts the water quality in Bezdan and Novi Sad is the higher electrical conductivity of the water, the high concentration of suspended solids, the increased concentration of nitrogen oxide, as well as the high value of $\mathrm{BOD}_{5}$. The Danube water quality is greatly influenced by all the countries through which the Danube flows before it reaches Serbia.

What seems to be the problem is the Zemun-Radujevac river course. During 2018., the water quality in Zemun was good, while in March was registered bad quality. In the hydrological station Zemun, parameters that were well above permitted values were fecal coliforms, ammonium ion concentration, insufficient oxygen saturation, and the highest recorded $\mathrm{BOD}_{5}$ value. Water quality is also good in Smederevo, but slightly better than in Zemun. Rivers Sava, Tisza and Tamis flow into the Danube on his course from Zemun to Smederevo. Here, the flow of the Danube is much larger than that of Zemun, and this is probably the reason for the slightly better water quality in Smederevo. This vast stream has much more pollutants than in Zemun, but on average, per litre, this value is smaller.

Accumulation - Djerdap Lake in Radujevac has a significant impact on better water quality. This reservoir is a vast "precipitator" or "filter", which with two dams holds a certain amount of pollutants. The same SWQI value in Bezdan and Radujevac indicates that pollutants are similarly represented in $\mathrm{mg} / \mathrm{l}$. Still, due to the large tributaries which enter into the Danube after the Bezdan, the water flow is much higher when leaving the country, and therefore the total pollutant concentration in water is higher.

The significant problems with the reduced quality of the Danube water in Serbia are the lack of wastewater treatment plants and insufficient financial resources for their construction, as well as the lack of filters for the treatment of water from sewage systems in larger cities and rural places.

\section{References}

Агенција за заштиту животне средине [Environmental Protection Agency] (2019). Резултати испитивања квалитета површинских и подземних вода 2018. [Results of surface and groundwater quality assessment 2018.]. Београд: Министарство за заштиту животне средине, Република Србија, 1-435. 
Bharti, N. \& Katyal, D. (2011). Water quality indices used for surface water vulnerability assessment. International journal of environmental sciences, 2 (1), 154173.

Bordalo, A., Teixeira, R. \& Wiebe, W. J. (2006). A Water Quality Index applied to an international shared river basin: the case of the Douro River. Environmental Management, 38 (6), 910-920.

Brankov, J., Milijašević, D. \& Milanović, A. (2012). The assessment of the surface water quality using the water pollution index: A case study of the Timok river (The Danube river basin), Serbia. Archives of Environmental Protection, 38 (1), 4961.

Breabăn, I. G., Ghețeu, D. \& Paiu, M. (2012). Determination of Water Quality Index of Jijia and Miletin Ponds, Bulletin UASVM Agriculture 69 (2) / 2012.

Драгићевић С., Љешевић М., Костадинов С., Игњатовић Љ., Миловановић С., Милановић М., Јовановић Б., Новковић И. \& Прица М. (2008). Анализа рецентног стања и степена загађења Топчидерске реке на територији општине Савски Венаu [Analysis of the recent case and extent of pollution of the Topcider River in the territory of the Savski venac municipality] Београд.

Hallock, D. (2002). A Water Quality Index for Ecology's Stream Monitoring Program.

Ismail, A. \& Robescu, L. (2017). Chemical water quality assessment of the Danube river in the lower course using water quality indices. UPB Scientific Bulletin, Series B: Chemistry and Materials Science, 79 (4), 51-62.

Jakovljević, D. (2012). Serbian and Canadian water quality index of Danube river in Serbia in 2010. Journal of the Geographical Institute "Jovan Cvijić" SASA, 62 (3), 1-18.

Kankal, N. C., Indurkar, M. M., Gudadhe S. K. \& Wate, S. R. (2012). Water Quality Index of Surface Water Bodies of Gujarat, India, Asian J. Exp. Sci., Vol. 26, No. 1, 39-48.

Lumb, A., Halliwell, D. \& Sharma, T. (2006). Application of the CCME Water Quality Index to Monitor Water Quality: A Case Study of the Mackenzie River Basin, Canada. Environmental Monitoring and Assessment, 113 (1-3), 411-429.

Milijašević Joksimović, D., Gavrilović, B. \& Lovrić Obradović, S. (2018). Application of the water quality index in the Timok river basin (Serbia). J. Geogr. Inst. Cvijic. 68 (3) (333-344).

Milanović, A., Milijašević, D. \& Brankov, J. (2011). Assessment of polluting effects and surface water quality using water pollution index: a case study of Hydrosystem Danube-Tisa-Danube, Serbia. Carpathian Journal of Earth and Environmental Sciences, 6 (2), 269-277.

Mladenović-Ranisavljević, I. (2012). Višekriterijumska analiza kvaliteta vode Dunava u Srbiji [Multi-criteria analysis of the Danube water quality in Serbia]. Doktorska disertacija [doctoral dissertation], Tehnički fakultet $\mathrm{u}$ Boru, Univerzitet $\mathrm{u}$ Beogradu, 1-170. 
Nistor, O. V., Botez, E., Andronoiu, D. G. \& Mocanu, G. D. (2012). Water quality in the Galati district. Journal of Environmental Protection and Ecology, 13 (2A), 862-868.

Pantelić, M., Dolinaj, D., Savić, S., Stojanović, V. M. \& Nadj, I. (2012). Statistical Analysis of Water Quality Parameters of Veliki Bački Canal (Vojvodina, Serbia) in the Period 2000-2009. Carpathian Journal of Earth and Environmental Sciences, 7 (2), 255-264.

Singh, K. P., Tiwar, K. A., Panigary, P. B. \& Mahato, K. M. (2013). Water Quality Indices Used for Water Resources Vulnerability Assessment Using GIS Technique: A Review. International Journal of Earth Sciences and Engineering, 6 (1), 1594-1600.

Takić, Lj., Mladenović-Ranisavljević, I., Vasović, D. \& Đorđević, Lj. (2017). The Assessment of the Danube River Water Pollution in Serbia. Water, Air, \& Soil Pollution, 10, 228-380.

Tyagi, S., Sharma, B., Singh, P. \& Dobhal, R. (2013). Water Quality Assessment in Terms of Water Quality Index. American Journal of Water Resources, 1 (3), 34-38.

Urošev, M., Milanović, A. \& Milijašević, D. (2009). Assessment of the river habitat quality in undeveloped areas of Serbia applying the RHS (river habitat survey) method. Journal of the Geographical Institute "Jovan Cvijić" SASA, 59 (2), 37-58.

Veljković, N. \& Jovičić, M. (2007). Danube river water quality analysis using Water Quality Index methodology. Proceedings from Conference on Actual Problems of Water Use and Protection, Yugoslav Society for the Water Protection, 36, 49-54.

Veljković, N., Lekić, D. \& Jovičić, M. (2008). Case study of Integrated Water Quality Management: Serbian Water Quality Index. Proceedings from XXIV Conference of the Danubian Countries on the Hydrological Forecasting and Hydrological Bases of Water Management, Slovenian National Committee for the IHP UNESCO, 171-178.

Veljković, N., Stanković, M. \& Milenković, S. (2000). Određivanje indeksa kvaliteta voda sliva Južne Morave primenom WQI metode [Determining water quality index of the Southern Morava basin by the application of WQI method]. In: A. Djukić (Ed.), Zaštita voda 2000 [Waters' Protection 2000]. Belgrade, Serbia: Jugoslovensko društvo za zaštitu voda.

Yogendra, K. \& Puttaiah, E. T. (2008). Determination of Water Quality Index and suitability of an urban waterbody in Shimoga Town, Karnataka, Proceedings of Taal 2007: The 12th World Lake Conference: 342-346.

Zakon o vodama [Water law] ("Sl. glasnik RS", br. 30/2010, 93/2012, 101/2016, $95 / 2018$ - dr. zakon).

Zhukinskii, V. N. (2003). Environmental Risk and Environmental Damage to Surface Water Quality: Topicality, Terminology, Quantitative Estimates. Water Resources, 30 (2), 191-198. 